\title{
An Examination of the Determinants of The Mode of Transport to Primary Health Facilities in A Developing Region
}

\author{
Olayinka Otun, Adeolu Dina, Adeola Bamigboye
}

Received: 24102014 / Accepted: 28102014 / Published online: 31122014

(c) 2014 Faculty of Geography UGM and The Indonesian Geographers Association

\begin{abstract}
Access to primary health facilities is a key determinant of the overall well being of the population in an area. In rural regions were distances to public facilities are usually longer compared to urban areas, it is not clear if people are still willing to walk to use these facilities. It is pertinent therefore to clarify such uncertainty since walking distance is a standard measure used to plan such public facilities particularly in rural regions. The objective of this study therefore is to provide a framework to determine the factors that will influence a health care service seeker in a developing region to walk or use other means of transport to a primary health facility. The case study for this research is Ijebu North Local Government Area of Ogun state made up of eleven urban and rural wards. One hundred and fifty households were selected at random for interview. Logit regression was used to describe how some predictor variables were used to explain the likelihood of a particular household walking to a primary health facility. The predicting model in this study was able to classify $80.0 \%$ of the cases correctly. This simply shows that the predictors (independent variables) contribute to the predicting power of the logistic regression model. The pseudo R-squares of Cox and Snell's R-square and Nagelkerke's $\mathrm{R}$ also show that our logistic model is relevant to predicting whether a household will walk or use a vehicle while attending a health facility. In our study, we noted that settlement status $(\mathrm{p}=0.00)$ and transport cost to health facility $(\mathrm{p}=0.00)$ contributed significantly to the prediction. This study also reveals that the odds for household members in an urban area to walk to the health facility often used is $88.1 \%$ lower than the odds for a household in a rural area. It was revealed that households that are poor are $49 \%$ times more likely to walk to the health facility they frequently used. The knowledge of the factors that will determine whether health care service seekers in a developing region will want to walk or not will assist government in the planning and provision of health facilities.
\end{abstract}

Keywords: Developing Region, Accessibility, Primary Health Facilities, Logistic Modelling, Transport modes

\begin{abstract}
Abstrak Akses ke fasilitas kesehatan yang bersifat primer merupakan faktor penentu kesejaheraan dari penduduk di suatu daerah. Pada wilayah pedesaan dengan jarak ke fasilitas umum yang lebih jauh dibandingkan perkotaan, ketersediaan orang-orang berjalan untu menggunakan fasilitas-fasilitas tersebut menjadi tidak jelas. Hal ini sangat relevan karena untuk mengklarifikasi ketidakpastian tersebut, dimana berjalan kaki menjadi ukuran standar yang digunakan untuk merencanakan fasilitias umum di daerah pedesaan. Penelitian uni bertujuan untuk menyediakan kerangka pemikiran untuk menentukan faktor yang berpengaruh terhadap pencari layanan keseahatan pada wilayah yang sedang berkembang, apakah dengan berjalan ataukan menggunakan moda transportasi lain untuk memperoleh fasilitas kesehatan primer. Studi kasus untuk penelitian ini adalah Pemerintah Daerah Ijebu Utara pada Provinsi Ogun-Nigeria yang terdiri dari wilayah kecamatan perkotaan dan pedesaan. Seratus lima puluh rumah tangga dipilih secara acak untuk interview. Regresi logit digunakan untuk mendiskripsikan beberapa variabel prediksi yang digunakan untuk kecenderungan rumah tangga terkait untuk berjalan memperoleh fasilitas kesehatan primer. Model prediksi pada daerah penelitian mampu mengklasifikasikan 80,0\% kasus dengan benar. Kondisi ini dengan sederhana menunjukan bahwa variabel prediksi (variabel independen) berkontribusi terhadap kemampuan prediksi dari model regresi logistik. Nilai pseudo R-squares dari Cox dan Snell R-square serta Nagelkerke R juga menunjukan bahwa model logistik relevan untuk memprediksi bahwa rumah tangga memilih berjalan atau menggunakan kendaraan untuk memperoleh akses pendidikan. Dalam penelitian ini, status permukiman $(p=0,00)$ dan biaya transportasi berkontribusi signifikan terhadap prediksi fasilitas kesehatan $(p=0,00)$. Studi ini juga menunjukan bahwa jumlah rumah tangga pada wilayah perkotaan yang bersedia untuk berjalan memperoleh fasilitas kesehatan adalah $88,1 \%$, lebih rendah dibandingkan rumah tangga pada wilayah pedesaan. Penelitian ini juga menunjukan bahwa rumah tangga miskin 49\% kali lipat bersedia untuk berjalan untuk memperoleh fasilitas kesehatan. Pengetahuan tentang faktor-faktor yang akan menentukan apakah pencari pelayanan kesehatan di daerah berkembang akan ingin berjalan atau tidak akan membantu pemerintah dalam perencanaan dan penyediaan fasilitas kesehatan.
\end{abstract}

Kata kunci: Wilayah berkembang, aksesbilitas, fasilitas kesehatan primer, model logistik, moda transportasi

\section{Introduction}

Access to primary health facilities is an important

Olayinka Otun, Adeolu Dina and Adeola Bamigboye Department of Geography and Regional Planning, Olabisi Onabanjo University email: otunwo@yahoo.com determinant of the overall well being of any given population in an area [Obrist et al., 2007; Kumar, 1999; Guagliardo \& Mark, 2004; Bagheri, et al., 2005, JeanFrederic, et al., 2013]. Lack of access can cause ill health 
and ill health perpetuates poverty among the populace. It is in recognition of this importance of health care service that the International Conference on Primary Health Care held at Alma-Ala in 1978 declared that health, which is a state of complete physical, mental and social well being, is a fundamental human right. The separating distance is a major determinant of physical access to primary health facilities especially in rural regions where density of population is often low and settlements are far apart. In rural regions distances to public facilities are usually longer compared to urban areas. However it is often assumed in public facilities location studies in developing regions that users of facilities will walk to them. Thus distance standard in facilities planning are usually based on this assumption of the users walking. For example the government in Ogun state in her policy on health [Ogun State Government, 2010] specify an average distance of five kilometers and maximum distance of ten kilometers to primary health centres. These standards are based on the perceived walking capability of health care service seekers. It has been observed by Rushton [1988] that decision makers don't always research into the basis for setting the ideal distance standard in public facility planning.

Health care service seekers often use different modes of transport to overcome the tyranny of distance by walking or use of commercial or private bicycles and vehicles. In modern times it is often more convenient to use a vehicle than to trek and there is limit to the extent people can walk and are willing to walk to use health facilities. In some developing regions there are areas without mechanized means of transport, there are areas where people cannot afford to pay for transport services and some settlements are remotely located away from primary health facilities. In such situations, will people be willing to walk to use primary health facilities? Following from the question raised, the focus of this study is to identify the factors that will determine whether health care service seekers in a developing region will want to walk to use primary health facility and the extent to which they are willing to walk. Such knowledge will assist the planners in the planning and provision of primary health care facilities. This research paper has been divided into three sections. Section one is the introduction and it discusses the research problem and objective of the study. Also contained in section one is the discussion of the study area, methodology and a review of the literature on access to public facilities. Section two of the paper discusses the research findings and section three is the conclusion.

The study area is discussed here to provide the background information such as the location and the mode of transport available in the area. The area used for this study is Ijebu North local government area of Ogun State, Nigeria. This local government area has been chosen to represent a typical region in the developing world. It consists of three urban centres and the remaining part is rural. This pattern allowed the implication of rural/urban place of residence of an health care service seeker on his readiness to walk to be examined in this study.

The local government area (LGA) has its headquarter in Ijebu Igbo and it is located at the northern end of Ogun state. The local government area is approximately located between latitude 6055' and $70 \mathrm{~N}$ and between longitude 3045; and 4005'E. The total land area of the local government area is about

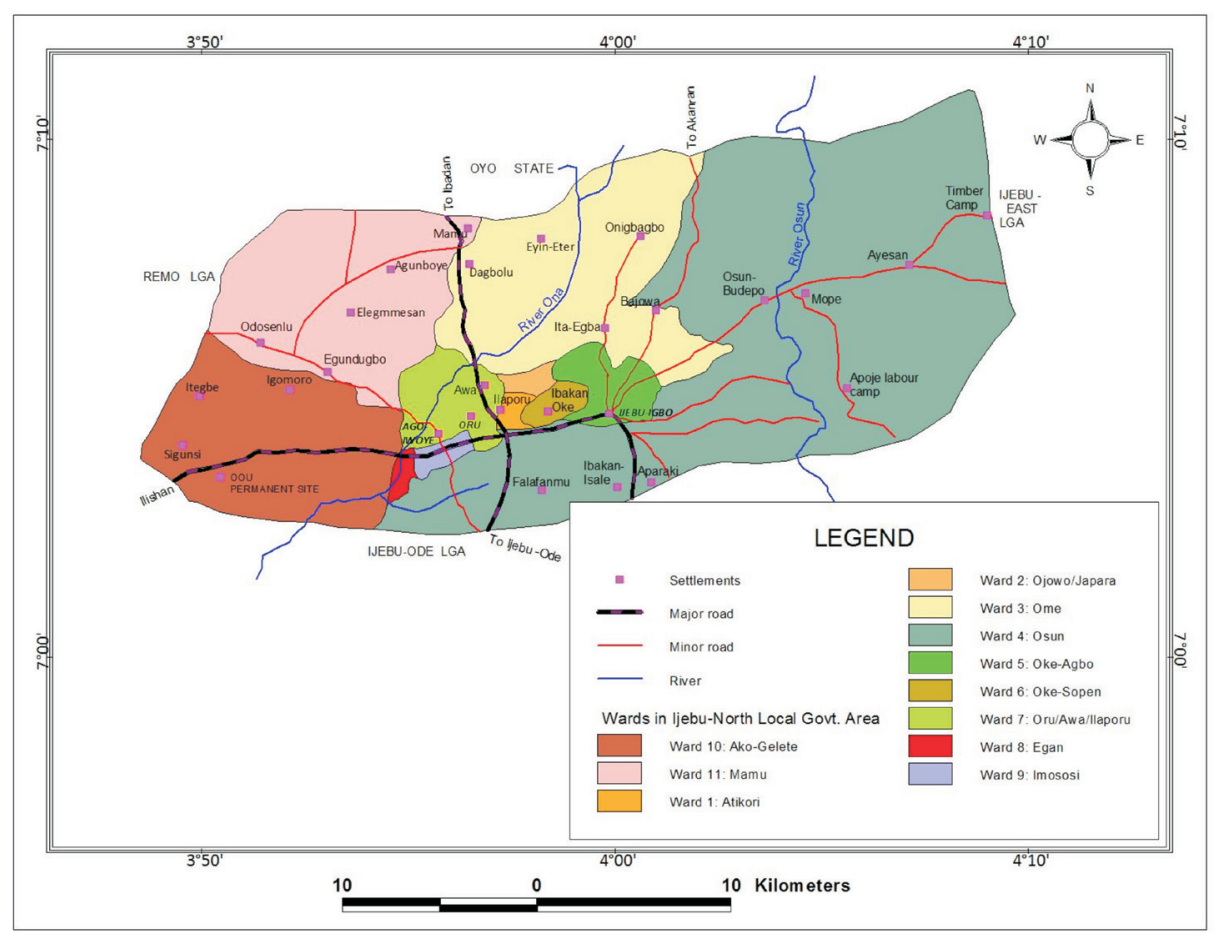

Figure 1. Map of Ijebu North Local Govenment Area, Ogun State 
967 square $\mathrm{km}$. The 2006 population of the LGA is 284,336 (National Population Commission). The LGA is bounded to the north by Lagelu LGA of Oyo state. To the east is Ijebu East and Ijebu Ode LGA is to the south west. To the west of the LGA is Ikenne LGA. Ijebu North LGA is partitioned into eleven (11) wards which are: Atikori, Oke Agbo, Oke Sopen, Omen, Osun, Oru/ Awa/Ilaporu, Ojowo/Japara, Egan, Imososi, Mamu and Ako Gelete. As shown in Table 1 some of the wards are urban and others are rural.

The dominant mode of transport available in Ijebu North Local Government Area is road. Roads are used for accessing public facilities in the local government area. Before the penetration of the colonial administrators, bush paths were the forms of transport routes in the study area. Some of these paths were later widen into motorable roads. The motorable roads are classified as either a main road or a secondary road. See Figure 1 for map of the road networks in Ijebu North Local Government Area.

\section{The Methods}

This section discusses the type of data used and all the methods used in this study in collecting and analyzing the collected data to achieve the objective of the study.

The main data for this study is from a household survey in Ijebu North local government area of Ogun state. The sampled households were selected from the eleven wards. Some of these wards form parts of the urban centres in the local government area and others are basically rural. Ward 1, Ward 2, Ward 5 and Ward 6 are the urban areas of Ijebu Igbo. Ward 8 and
Ward 9 are the urban part of Ago-Iwoye and Ward 7 covers Oru, Awa and Ilaporu which are also urban areas. One hundred questionnaires were administered in the urban wards and fifty in the rural wards. The number of questionnaires is for convenience sake given the time and resources available for the study. The questionnaires were administered on house hold basis and in proportion to the projected population of the wards as shown in Table 1. The sampled households were selected at random starting from one end of the ward and moving progressively to the end of the ward.

The characteristics of the interviewed households were presented in frequency tables and the logistic regression model was used to establish the nature of the relationship between the dependent variable and the predictors.

A summary of the literature on physical access to public facilities is presented in this section. Accessibility can be seen as the ease with which the users are able to use the services provided by a public facility. Most studies on access to public facilities often focus on the barriers to the use of facilities. According to Peters et al. [2008] the dimensions of barriers to assessing health services has been categorized into four: (1) geographical accessibility (2) availability, (3) affordability and (4) acceptability.

Public service are form of public goods that the users travel to consume or the service are delivered to the consumer like the case of a fire fighting service [Lea, 1982]. Thus the separating physical distance between a user and the facility serve as a barrier to access the facility. Researches relating to improving physical access to public facilities cover studies on: location and

Table 1. Administration of questionnaires

\begin{tabular}{lcrrr}
\hline Ward & Status & 1991 actual census & $\begin{array}{l}\text { 2013 projected } \\
\text { population }^{* *}\end{array}$ & Number of questionnaires \\
\hline Ward 1 (Atikori) & urban & 13432 & 25117 & 13 \\
Ward 2 (Ojowo/Japara) & urban & 11321 & 21169 & 11 \\
Ward 3 (Ome) & rural & 1149 & 2149 & 5 \\
Ward 4 (Osun) & rural & 6524 & 12199 & 27 \\
Ward 5 (Oke Agbo) & urban & 16626 & 31089 & 16 \\
Ward 6 (Oke Sopen) & urban & 23538 & 44014 & 22 \\
Ward 7 (Oru/Awa/Ilaporu) & urban & 11445 & 21401 & 11 \\
Ward 8 (Egan) & urban & 18795 & 35145 & 18 \\
Ward 9 (Imososi) & urban & 10833 & 20257 & 10 \\
Ward 10 (Ako Gelete) & rural & 2132 & 3987 & 9 \\
Ward 11 (Mamu) & rural & 2172 & 4061 & 9 \\
Total & & & & 150 \\
\hline
\end{tabular}

Sources:

* National Population Commission

** Projected population: The Annual growth rate used for 1991 - 2000 was 2.60\%. 2.75\% was used for 2001 2005 while $3.18 \%$ was used from $2006-2013$. 
allocation modeling of public facilities [Ayeni, 1985; Ayeni, 1986; Rushton, 1988; Owoola, 2002], improving the network links between the users and facilities [Moller-Jensen and Richard Y.K., 2001; Schoeps et al. 2011] and improving the transport cost between the demnd points and public facilities. The focus in this study is on the mode of transport used to primary health facilities.

To understand the location of service centres visa-vis the demand points the central place theory (CPT) is fundamental. The theory attempts to explain the size, number and spacing of service centres providing services to the surrounding population. The concepts of threshold and range of the CPT are fundamental to explaining location of public facilities. The threshold ensures that there exists a minimum number of people that generate enough demand to keep the service running. Furthermore, there exists a maximum distance above which consumers would find it more profitable to visit a nearer service centre. This maximum distance was called the range [Berry, 1967; Christaller, 1933]. The range is a measure of physical accessibility of a particular service.

The issue of accessibility as a concept is the most commonly articulated and the least understood in locational studies [Ayeni and Rushton, 1986; Owoola, 1996]. On one hand, it is interpreted in terms of physical proximity of locations that permit involvement in activity space of a given region [Burns, 1978; Moseley, 1979; Owens and Shaw, 1972]. Others have interpreted the concept in terms of matching the distribution of services to the distribution of potential population to be served using the logic of central place theory [Gould, 1978; Fisher and Rushton, 1988]. However, of particular interest in this study is physical accessibility defined as the spatial separation of service users from service centres. Thus physical accessibility is the ease of movement to activity locations and it is the distance people are willing to travel to utilize a service [Ikporukpo, 1987; Okafor, 1989; Ayeni, 1989].

Most published measures of spatial accessibility to health have been classified into:, distance to nearest provider, average distance to a set providers, and gravitational models of provider influence [Guagliardo, 2004]. Travel distance to nearest provider is typically measured from a patient's residence or from a population centre. Travel distance to nearest provider has been assumed to be a good measure of spatial accessibility for rural areas, where provider choices are very limited and the nearest provider is also the most likely to be used Russell [2008]. Maximal service distance is another measure of travel distance to nearest provider, but here the distance, time or cost of a user most distant from a provider is considered. The maximal service distance is a common measure of articulating location of public facilities in the literature. Another measure of spatial accessibility is the average travel distance to provider [Ulises and Carina, 2012]. For this measure the distance from any patient or population to all providers within a system is summed and average. Gravity models are a combined indicator of accessibility and availability of health service. Gravity models attempt to represent the potential interaction between any population point and all service points within a reasonable distance, discounting the potential with increasing distance or travel impedance.

The focus of this study is on determinants of mode of transport used by a health care service seeker. Such trips can be made by different modes of travel and the determination of the choice of travel mode by individual is known as modal split [Salter, 1983]. Modal split model therefore is the public transportation version of the general model of human choice that explains how people select between competing alternatives [UCLA, 2011]. Modal split could be analyzed using probabilistic models such as the discriminant analysis, probit and the multinomial or dichotomous logit models [Okoko, 2006]. The focus here is on choice between use of vehicle and walking to health facilities. The discussion above is a summary of some of the researches on physical access and mode of transport to public facilities. Following from this review of the literature, the key findings of this study are presented in the next section.

\section{Result and Discussion}

The findings in this study are discussed in this section. The characteristics of the households interviewed are discussed according to whether they reside in rural or urban area. The result from the application of the regression model framework to determine the willingness of health care seekers to walk or use some other modes of transport is discussed in this section.

The characteristics of the households selected for interview are presented in Table 2. The discussions include the socio-economic and demographic characteristics of the households and the characteristics of transport used while attending primary health care service. The discussion below focused on where the characteristics of households in urban and rural areas is significantly different and this difference has implication on the predictive logistic model in the next section. The households were divided into two categories of those that spend below $\$ 2$ a day (categorized as poor) and those that spend above $\$ 2$ a day. Table 2 shows that $41 \%$ in urban areas and $78 \%$ in rural areas spend below $\$ 2$ a day. This observed difference and the importance of expenditure on mode of transport used made the variable to be included in the logistic regression model in the next section. This study also revealed that $17 \%$ in urban area and $50 \%$ of households in rural areas trek to the health facilities they use often. The proportion of people that trek is our dependent variable in the logistic model in the next section. It is shown in Table 2 that $58 \%$ of households in urban areas and $38 \%$ of households in rural areas 
Table 2. Characteristics of the households in the study area

\begin{tabular}{|c|c|c|c|c|}
\hline \multirow[t]{2}{*}{ Attributes of Head of Household } & \multicolumn{2}{|c|}{ Urban } & \multicolumn{2}{|c|}{ Rural } \\
\hline & Frequency & Percent & Frequency & Percent \\
\hline \multicolumn{5}{|l|}{ Gender } \\
\hline Male & 49 & 49.0 & 22 & 44.0 \\
\hline Female & 51 & 51.0 & 28 & 56.0 \\
\hline \multicolumn{5}{|l|}{ Age } \\
\hline Below 18 years & 5 & 5.0 & 3 & 6.0 \\
\hline $18-40$ years & 60 & 60.0 & 33 & 66.0 \\
\hline $41-60$ years & 32 & 32.0 & 13 & 26.0 \\
\hline Above 60 years & 3 & 3.0 & 1 & 2.0 \\
\hline \multicolumn{5}{|l|}{ Monthly income } \\
\hline Less than N18,000 & 25 & 25.0 & 22 & 44.0 \\
\hline $\mathrm{N} 18,000-\mathrm{N} 30,000$ & 33 & 33.0 & 12 & 24.0 \\
\hline N30,001 - N60,000 & 21 & 21.0 & 7 & 14.0 \\
\hline N60,001 - N100,000 & 12 & 12.0 & 0 & 0.0 \\
\hline Above N100,000 & 5 & 5.0 & 2 & 4.0 \\
\hline \multicolumn{5}{|l|}{ Amount spend per day } \\
\hline Below N320 & 41 & 41.0 & 39 & 78.0 \\
\hline Above N320 & 59 & 59.0 & 11 & 22.0 \\
\hline \multicolumn{5}{|l|}{ Type of health facility often used } \\
\hline Orthodox & 57 & 57.0 & 15 & 30.0 \\
\hline Traditional & 13 & 13.0 & 15 & 30.0 \\
\hline Chemist & 30 & 30.0 & 18 & 36.0 \\
\hline \multicolumn{5}{|l|}{ Ownership of health facility } \\
\hline Public & 52 & 52.0 & 24 & 48.0 \\
\hline Private & 39 & 39.0 & 17 & 34.0 \\
\hline \multicolumn{5}{|c|}{ Means of transport to health facility often used } \\
\hline Trek & 17 & 17.0 & 25 & 50.0 \\
\hline $\mathrm{Cab}$ & 20 & 20.0 & 2 & 4.0 \\
\hline Commercial motorcycle/Tricycle & 45 & 45.0 & 18 & 36.0 \\
\hline Private motorcycle & 10 & 10.0 & 4 & 8.0 \\
\hline Private vehicle & 7 & 7.0 & 1 & 2.0 \\
\hline \multicolumn{5}{|l|}{ Distance of residence to health facility often } \\
\hline use & 33 & 33 & 19 & 38.0 \\
\hline Less than $1 \mathrm{~km}$ & 46 & 46 & 21 & 42.0 \\
\hline $1-2 \mathrm{~km}$ & 20 & 20 & 9 & 18.0 \\
\hline $3-4 \mathrm{~km}$ & 1 & 1 & 0 & 0 \\
\hline \multicolumn{5}{|l|}{$5-6 \mathrm{~km}$} \\
\hline \multicolumn{5}{|l|}{ Perception of accessibility of health facility } \\
\hline Very accessible & 28 & 28.0 & 16 & 32.0 \\
\hline Accessible & 58 & 58.0 & 19 & 38.0 \\
\hline Not accessible & 14 & 14.0 & 15 & 30.0 \\
\hline \multicolumn{5}{|c|}{ Distance willing to travel to use health facility } \\
\hline Less than $1 \mathrm{~km}$ & 21 & 21.0 & 9 & 18.0 \\
\hline Between 1 - 2km & 30 & 30.0 & 17 & 34.0 \\
\hline Between 2- 4 km & 28 & 28.0 & 10 & 20.0 \\
\hline Between 4 - 7 km & 16 & 16.0 & 7 & 14.0 \\
\hline Between $7-10 \mathrm{~km}$ & 5 & 5.0 & 10 & 20.0 \\
\hline Above $10 \mathrm{~km}$ & 0 & 0.0 & 2 & 4.0 \\
\hline
\end{tabular}


continue Table 2 ..........

Reasons for preferring a particular health facility

Cheapness

Reliability of services

Safety of the premises

Accessibility

Convenience

Average transport cost from home to health facility

N20 - N50

N51 - N100

N101 - N150

Above N150

Average movement time from home to health facility

Less than 5 minutes

10 mins - 30 mins

30 mins 1 hour

26

Usual problems encountered on your trip to the health facility

Bad road condition

Long distance covered

Insufficient transport facilities

High transport cost

Poor management of vehicles

perceived the health facilities in their area as accessible The difference and the importance of perception of users on accessibility made the variable to be included in the logistic regression model.

In this section we are going to examine the factors that determine whether a user of health facility will walk or go by some means of vehicles to the health facility. Thus the dependent variable (i.e. the variable we want to predict) is dichotomous that indicates whether the user will walk or not. Of the independent variables (the predictors), the amount of expenditure per day (to measure level of poverty), the estimated distance to health facility and the user's perception of accessibility of the health facility are of particular interest to the researcher. The binary logistic regression is used to model and examine the relationship above. A logistic regression model allows us to establish a relationship between a binary outcome variable and a group of predictor variables [UCLA, 2011].

Binomial (or binary) logistic regression is a form of regression which is used when the dependent variable is a dichotomy and the independent variables are of any type. The goal is to find the best set of coefficients so that cases that belong to a particular category will, when using the equation have a very high calculated probability that they will be allocated to that category. This enables new cases to be classified with a reasonably high degree of accuracy as well.

The dependent variable and the independent variables used in the logistic regression to model the determinants of the means of transport to health facilities are summarized Table 3 .

Using the variable names above the logistic
25

12

1

26

25

12

1

20

55

24

$\begin{array}{lll}26.0 & 14 & 28.0 \\ 25.0 & 13 & 26.0 \\ 12.0 & 6 & 12.0 \\ 1.0 & 0 & 0.0\end{array}$

$\begin{array}{lll}26.0 & 14 & 28.0 \\ 25.0 & 13 & 26.0 \\ 12.0 & 6 & 12.0 \\ 1.0 & 0 & 0.0\end{array}$

$\begin{array}{lll}20 & 11 & 22.0 \\ 55 & 23 & 46.0 \\ 24 & 16 & 32.0\end{array}$

\begin{tabular}{llll}
16 & 16.0 & 13 & 26.0 \\
15 & 15.0 & 9 & 18.0 \\
7 & 7.0 & 5 & 10.0 \\
6 & 6.0 & 8 & 16.0 \\
1 & 1.0 & 3 & 6.0 \\
\hline
\end{tabular}

regression or prediction equation for this study is specified as:

$\operatorname{Logit}(p)=\log (p /(1-p))=\beta 0+\beta 1^{\star} X 1+\beta 2^{\star} X 2+$ $\beta 3^{\star} \mathrm{X} 3+\beta 4^{\star} \mathrm{X} 4+\beta 5^{\star} \mathrm{X} 5+\beta 6^{\star} \mathrm{X} 6+\ldots$

Where $\mathrm{p}$ is the probability of success.

$\mathrm{X} 1$ = Dailyexp1

$\mathrm{X} 2$ = Peraccess 1

$\mathrm{X} 3$ = Gender 1

The remaining variables are continous

$\mathrm{X} 4$ = Income

$\mathrm{X} 5=$ Distanctohf

$\mathrm{X} 6=$ Transcostohf

$\mathrm{X} 7=$ Age - Age of respondent

$\mathrm{X} 8=\mathrm{Rural} /$ Rural status

Writing the logistic regression equation more formally:

Let $y$ be the binary outcome variable indicating failure/success (in our study it will be walk/don't walk) with $0 / 1$ and $\mathrm{p}$ be the probability of $\mathrm{y}$ to be 1 and let $\mathrm{X} 1$, ..., Xk be a set of predictor variables. The independent variables are either dichotomous or continuous. Where the data are categorical (i.e. options are in categories such as in assessing the perception of access) the options are recoded into a dichotomous variable as "accessible" and "not accessible".

One way to assess our logistic regression model is to examine the number of the cases of the dependent variable it is able to predict correctly. We will then compare the level of accuracy of the prediction of the null model with that of the model containing all our 
Table 3. Definition of the data in the regression model

\begin{tabular}{|c|c|c|c|}
\hline $\begin{array}{l}\text { Variable } \\
\text { name }\end{array}$ & Meaning & Options & Reason for choice of variable \\
\hline & Dependent & & \\
\hline \multirow[t]{2}{*}{ Trek } & $\begin{array}{l}\text { Means of getting to the health } \\
\text { facility }\end{array}$ & $\begin{array}{l}\text { Trek }=1 \\
\text { Vehicle }=0\end{array}$ & $\begin{array}{l}\text { The variable to be predicted. We want } \\
\text { to know why some household trekked } \\
\text { to health facilities. }\end{array}$ \\
\hline & $\begin{array}{l}\text { Independent variables (Categori- } \\
\text { cal) }\end{array}$ & & \\
\hline Dailyexp & Daily expenditure by respondent & $\begin{array}{l}\text { Below } \$ 2=1 \\
\text { Above } \$ 2=0\end{array}$ & $\begin{array}{l}\text { To know the effect of daily expenditure } \\
\text { on mode of transport to health facilities }\end{array}$ \\
\hline Peraccess & $\begin{array}{l}\text { Perception of access to health } \\
\text { facility }\end{array}$ & $\begin{array}{l}\text { Far } \quad=1 \\
\text { Not far }=0\end{array}$ & $\begin{array}{l}\text { How perception of access determines } \\
\text { whether a household will walk to } \\
\text { health facility }\end{array}$ \\
\hline Gender & Gender of respondent & $\begin{array}{l}\text { Male }=1 \\
\text { Female }=0\end{array}$ & $\begin{array}{l}\text { How being a male or female affect } \\
\text { whether the head of household will } \\
\text { walk to health facility or not }\end{array}$ \\
\hline \multirow[t]{2}{*}{ Rural_Urb } & Rural/urban status of settlement & $\begin{array}{l}\text { Rural }=0 \\
\text { Urban }=1\end{array}$ & $\begin{array}{l}\text { The rural/ urban status of household } \\
\text { will determine whether a household } \\
\text { will walk to health facility }\end{array}$ \\
\hline & Independent variables (Continous) & & \\
\hline Income & Income of respondent & & $\begin{array}{l}\text { Income of the household will deter- } \\
\text { mine the ability of the household to use } \\
\text { a vehicle or not. }\end{array}$ \\
\hline
\end{tabular}

Table 4. Classification table for the model

\begin{tabular}{lcccc}
\hline & \multicolumn{3}{c}{ Predicted } \\
\hline \multicolumn{1}{r}{ Observed } & Use of vehicle & Trek & Percent correct \\
& 0 & 1 & \\
\hline Use of vehicle & 0 & 98 & 10 & 90.7 \\
Trek & 1 & 20 & 22 & 52.4 \\
Overall percentage & & & 80.0 \\
\hline
\end{tabular}

Computed by author with SPSS 15, 2011

Table 5. Omnibus test: the model chi square

\begin{tabular}{ccc}
\hline Chi-square & Degrees of freedom & Significance \\
\hline 53.413 & 8 & 0.00 \\
\hline
\end{tabular}

Source: Computed by author with SPSS 15, 2011

Table 6. Model summary

\begin{tabular}{cc}
\hline Cox \& Snell R square & Nalgelkerke R square \\
\hline 0.295 & 0.425 \\
\hline
\end{tabular}


independent variables (full model) as shown in Table 4. The table shows that 98 cases are observed to be 0 and are correctly predicted to be 0 . Also cases that that are not correctly predicted are shown. Ten cases are observed to be 0 but are predicted to be 1 . The overall percent of cases that are correctly predicted by the model is $80 \%$. Table 4 above show that our model was able to classify $80.0 \%$ of the cases correctly.

The model chi square shown in Table 5 is used to test the overall significance of the predictors in the regression model. The analysis here involves comparing the null model (a model containing only the constant) and the full model ( a model with all the predictor variables). Table 5 shows a chi-square value of 53.413 and a probability of $\mathrm{p}<0.00$. Thus the indication is that the null model has a poor fit and that the predictors have significant effect in predicting the dependent variable.

There is no close analogous statistic in logistic regression to the coefficient of determination (R2). The model summary in Table 6 below provides some approximations to R2 and they are called pseudo R-squares. Cox and Snell's R-square attempts to imitate $\mathrm{R}$ square based on "likelihood", but its maximum can be (and usually is ) less than 1.0 making it difficult to interpret. Here it is indicating that $29.5 \%$ of the variation in the dependent variable is explained by the logistic model.

The Nagelkerke modification that does range from 0 to 1 is a more reliable measure of the relationship. Nagelkerke's R will normally be higher than the Cox and Snell measure. In our case it is 0.425 indicating a moderate relationship of $42 . \%$ between the predictors and the prediction.

The logistic coefficients $(\beta)$ are the values for the logistic regression equation for predicting the dependent variable from the independent variable. They are in log-odds units. The coefficients tell you about the relationship between the independent variables and the dependent variable, where the dependent variable is on the logit scale. These estimates tell the amount of increase (or decrease, if the sign of the coefficient is negative) in the predicted log odds of success that would be predicted by one unit increase (or decrease) in the predictor, holding all other predictors constant. For the independent variables which are not significant, the coefficients are not significantly different from 0 , which should be taken into account when interpreting the coefficients. In table 7 the Wald statistic and associated probabilities provide an index of the significance of each predictor/coefficient in the equation. The Wald statistic has a chi-square distribution. The simplest way to assess Wald is to take the significance value and if less than 0.05 reject the null hypothesis as the variable does make a significant contribution.

The logistic regression coefficients are in logodds units and difficult to interpret, so they are often converted into odds ratios. This has been done in table 7 by exponentiating the coefficient $(\mathrm{eB})$, and the result are displayed at the right-most column of the table and labeled “Exp(B)".

In our study, we note that the independent or predictor variables: Rural_Urb (Settlement status) $(\mathrm{p}=0.00)$ and Transcostohf (transport cost to health facility) ( $p=0.00)$ contributed significantly to the prediction of the regression model. The researcher may want to drop independent variables from the model when their effect is not significant by the Wald statistic. The $\operatorname{Exp}(\mathrm{B})$ column in Table 7 presents the extent to which raising the corresponding predictor variable by one unit influences the odds ratio. We can interpret $\operatorname{Exp}(\beta)$ in terms of the change in odds. If the value exceeds 1 then the odds of an outcome occurring increase; if the figure is less than 1, any increase in the predictor leads to a drop in the odds of the outcome occurring.

Households in urban areas are not likely to walk to health facility compared to households in rural areas. For a household in an urban area (coded as 1), we expect to see 0.119 decrease $(\beta=-2.125)$ in the odds of trekking (the chances of trekking decreases) to the health facility often used. Another way to express this in terms of percent change is to say that the odds for a household in an urban area to walk to the health facility often used is $(100 \%-11.9 \%) 88.1 \%$ lower than the

Table 7. Variables in the equation

\begin{tabular}{lrrrrrr}
\hline \multicolumn{1}{c}{ Variable } & B & S.E & Wald & df & Sig. & Exp(B) \\
\hline Dailyexpen & 0.712 & 0.560 & 1.617 & 1 & 0.203 & 1.491 \\
Percaccess & 1.458 & 0.836 & 3.039 & 1 & 0.81 & 4.297 \\
Gender & -0.435 & 0.455 & 0.915 & 1 & 0.339 & 0.647 \\
Income & -0.026 & 00.014 & 3.801 & 1 & 0.051 & 0.974 \\
Distancohf & 0.103 & 0.388 & 0.07 & 1 & 0.791 & 1.108 \\
Transcostohf & 0.039 & 0.09 & 17.219 & 1 & 0.000 & 1.962 \\
Age & 0.008 & 0.019 & 0.155 & 1 & 0.694 & 1.008 \\
Rural_Urb & -2.125 & 0.546 & 15.144 & 1 & 0.00 & 0.119 \\
Constant & 2.339 & 1.061 & 4.860 & 1 & 0.27 & 10.371 \\
\hline
\end{tabular}


odds for a household in a rural area.

From Table 7 we can derive that for every one unit increase in transport cost, we expect to see 1.962 increase in the odds of trekking $(\beta=0.039)$ to the health facility frequently used. If the transport cost should increase by one unit, holding all other predictors constant, the odds for a house hold to trek to the health facility frequently used will increase by $96 \%$.

Apart from settlement status and transport cost that are significant in explaining the outcome of the logit model we also examined the relationship between the amount expended daily by the households and the mode of getting to the health facility (trek/ non trek. The $\operatorname{Exp}(\beta)$ value associated with Dailyexp (Daily expenditure) is $1.491(\beta=0.712)$. Hence when

\section{References}

Ayeni, B., \& Rushton, G. (1986), Distributional equity and efficiency in the locational analysis of public facilities: a case study, The Nigerian Geographical Journal 28-29:1-2.

Ayeni, B. (1989), Normative analysis of the location of rural public facilities, Department of Geography, University of Ibadan, Ibadan, Nigeria.

Ayeni, B. (1991), Public facility location planning using maximal service distances: An Example, Research for Development 7:1-2.

Berry, B.J.L. (1967), Geography of market centers and retail distribution, Prentice Hall, Inc.

Burns, L.D. (1978), Transportation, temporal and spatial components of accessibility, Lexington Books, Mass.

Fisher, H.B., \& Rushton, G. (1988), Spatial efficiency of service locations and the regional development process, Papers of the Regional Science Association 42.

Guagliardo, F.M. (2004), Spatial accessibility of primary care: Concepts, methods and challenges, International Journal of Health Geographics 3(3).

Ikporupko, C.O. (1987), An analysis of the accessibility of public facilities in Nigeria, Socio-Econ. Plann. Sci. 21.

Jean-Frederic, L., Mark, F.H., \& Grant, R. (2013), Patient-centred access to health care: conceptualising access at the interface of health systems and populations, International Journal for Equity in Health: doi:10.1186/1475-9276-12-18.

Kumar, N. (1999), Locational analysis of public and private health services in Rohtak and Bhiwani Districts, (India), 1981 to 1996, Centre for the Study of Regional Development.

Lea, A. C. (1982), Public Facility Location Models and the Theory of Impure Public Goods, Sistemi Urbani 3.

Moller-Jensen, L., \& Richard Y.K. (2001), Exploiting available data sources: location/ allocation modeling for health service planning in rural Ghana, Danish Journal of Geography (101)1 : 145 - 153.
Dailyexp is raised by one unit (i.e. if the respondent is poor - spends less than $\$ 2$ or N320 a day and coded as 1) the odds ratio is 1.491 times as large and therefore households that are poor are $49 \%$ times more likely to walk to the health facility they frequently used.

We derive the following predicting logistic regression equation from the parameters in table 7 .

$\log (\mathrm{p} / 1-\mathrm{p})=2.339+0.712$ Dailyexpen + 1.458Percaccess - 0.435Gender - 0.026Income + 0.103Distancohf +0.039 Transcostohf +0.008 Age 2.125Rural_Urb

Where $\mathrm{p}$ is the probability of walking to the health centre. The equation above can be used to predict the outcome for a particular case.

Moseley, M.J. (1979), Accessibility: The Rural Challenge, Methuen and Company, London.

Obrist ,B., Iteba, N., Lengeler, C., Makemba, A., Mshana, C., et al. (2007), Access to health care in contexts of livelihood insecurity: A framework for analysis and action. PLoS Med 4(10) : 1584 - 1588. doi:10.1371/journal.pmed.0040308.

Ogun State Government (2010), Draft of the Ogun State Strategic Health Development Plan 2010, Ministry of Health, Abeokuta.

Okafor, S. I. (1989), The population factor in public service provision in Nigeria, Applied Geography (9)2: 23-33.

Okoko, E. (2006), Urban Transportation Planning and Modeling, MillenniumPublisher, Akure.

Owoola, M. A. (2002), Between policy and practice decision support system-based assessment of facility location planning in Nigeria, A paper presented at a symposium on geospatial theory, processing and applications 2002, Ottawa.

Rushton, G. (1988), The Roepke Lecture in Economic Geography: Location Theory, Location-Allocation Models, and Service Development Planning in the Third World, Economic Geography 64.

Russell, S. (2008), Demand-side factors affecting health seeking behavior in ghana. GeorgeTown University Journal Health Services 5 (1).

Salter, R J. (1983), Highway Traffic Analysis and Design, Macmillan Press Ltd, London.

Schoeps, A., Gabrysch, S., Niamba, L., Sié, A., \& Becher, H. (2011), The effect of distance to health-care facilities on childhood mortality in rural Burkina Faso. American Journal of Epidemology 173(5):492498.

Toregas, V., Swain, R.R., Revelle, C., \& Bigman, L. (1971), The Location of Emergency Service Facilities, Operations Research 19.

Ulises, H.M., \& Carina, K. (2012), Geographical accessibility and spatial coverage modeling of the primary health care network in the Western Province of 
Rwanda. International Journal of Health Geographics.11(40): 2 - 11. doi:10.1186/1476-072X-11-40

Wikipedia encyclopedia (2011), Logistic regression

World Health Organisation (1978), The alma-ata declaration, Geveva, Available at: http://www.who.int/

UCLA (2011). Annotated SPSS Output: Logistic Regression, available at http://www.ats.ucla.edu/stat/spss/ output/logistic.htm 